\title{
A new formulation of oxalic acid for Varroa destructor control applied in Apis mellifera colonies in the presence of brood
}

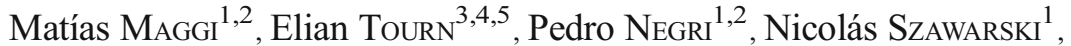 \\ Alfredo Marconi ${ }^{3,4,5}$, Liliana Gallez ${ }^{6}$, Sandra Medici ${ }^{1,2}$, Sergio Ruffinengo ${ }^{7}$, \\ Constanza Brasesco ${ }^{1}$, Leonardo De Feudis ${ }^{1}$, Silvina Quintana ${ }^{8}$, Diana SAMmataro 9 , \\ Martin EGUARAs ${ }^{1,2}$
${ }^{1}$ CIAS, Centro de Investigación en Abejas Sociales (ex Laboratorio de Artrópodos), Facultad de Ciencias Exactas y Naturales, Universidad Nacional de Mar del Plata, Funes 3350, 7600, Mar del Plata, Argentina
${ }^{2}$ CONICET, Consejo Nacional de Investigaciones Científicas y Técnicas, Rivadavia1917, C1033AJ Buenos Aires, Argentina
${ }^{3}$ Departamento de Agronomía, Universidad Nacional del Sur, Bahía Blanca, Buenos Aires, Argentina
${ }^{4}$ Ministerio de Agricultura, Ganadería y Pesca de la Nación, EEA INTA Bordenave, Bahía Blanca, Buenos Aires, Argentina
${ }^{5}$ Cooperativa de Trabajo Apícola Pampero Ltda., Bahía Blanca, Buenos Aires, Argentina
${ }^{6}$ LabEA, Depto. Agronomía, Universidad Nacional del Sur, 8000, Bahía Blanca, Argentina ${ }^{7}$ Cátedra de Apicultura, Facultad de Ciencias Agrarias, Universidad Nacional de Mar del Plata, 7620, Balcarce, Argentina
${ }^{8}$ Laboratorio de Biología Molecular, Fares Taie Instituto de Análisis, Mar del Plata, Argentina ${ }^{9}$ USDA ARS Carl Hayden Honey Bee Research Center, Tucson, AZ, USA

Received 14 July 2014 - Revised 4 August 2015 - Accepted 26 October 2015

\begin{abstract}
An organic product based on oxalic acid was evaluated for use in Varroa control under spring/summer climatic conditions in Argentina. The formulation consists of four strips made of cellulose impregnated with a solution based on oxalid acid. Forty-eight beehives were used to assess the product efficacy. Residues of the product were also tested in honey, bees, and wax. Each trial had respective control groups without oxalic treatment. At the beginning of the experiment, four strips of the formulation were applied to the colonies belonging to the treated group. Falling mites were counted after 7, 14, 21, 28, 35, and 42 days. After the last count, the strips were removed and colonies received two flumethrin strips for 45 days. Falling mites were counted throughout this period. Average efficacy of the organic product was $93.1 \%$ with low variability. This product is an organic treatment designed for Varroa control during brood presence and represents a good alternative to the synthetic treatments.
\end{abstract}

Varroa destructor / control / oxalic acid / bee brood / Argentina

\section{INTRODUCTION}

Varroa destructor (Acari: Varroidae), an obligate ectoparasitic mite of the honey bee, Apis

Corresponding author: M. Maggi, biomaggi@gmail.com

Manuscript editor: Yves Le Conte mellifera (Hymenoptera: Apidae), feeds on the hemolymph of adult bees, larvae, and pupae in capped brood cells. In Argentina, severe $V$. destructor infestation of $A$. mellifera results in honey bee colony death within 1 to 2 years of initial infestation (Eguaras and Ruffinengo 2006). In recent years, resistance to acaricides has become a major problem in the control of mite populations. Increased tolerance to the most widely used synthetic active ingredients has been 
observed (Maggi et al. 2010a, 2011). Because of the resistance to acaricides, there is a renewed interest in Argentina for substances of natural origin, such as essential oils and their components or organic acids, especially formic acid and oxalic acid (Eguaras et al. 2001, 2003; Maggi et al. 2010b; Ruffinengo et al. 2014). This situation related to Varroa resistance has been observed around the world (Sammataro et al. 2005).

Oxalic acid (OA) is widely used for controlling $V$. destructor because of its high efficacy ( $>90 \%)$ and low risk of hive contamination (Gregorc and Planinc 2001, 2002; Nanetti et al. 2003; Marinelli et al. 2006; Rademacher and Harz 2006; Bacandritsos et al. 2007). OA is applied to colonies by spraying or trickling a solution of $\mathrm{OA}$ and sugar-water over the bees or by evaporating crystals with heat (Rademacher and Harz 2006). Hovewer, most tests have been carried out during a broodless period, and have reported more than $95 \%$ efficacy (Higes et al. 1999; Charriere and Imdorf 2002). So, mite mortality after treatment with oxalic acid seems to be directly influenced by the presence of brood because oxalic acid does not kill the mites in sealed brood cells (Imdorf et al. 2003). Several reports agree on the use of oxalic acid when no brood is present in winter (Barbero et al. 1997). Its efficacy when brood is present is around $60 \%$ (Charrière 1997; Rademacher and Harz 2006). Thus, the usefulness of the acid seems limited in warm climates with a long brood rearing period.

Taking into account that oxalic acid is a suitable compound for the control of $V$. destructor in broodfree colonies during the autumn and winter period within the concept of Integrated Varroa Control, the major challenge to scientists is to develop a new formulation that can be used during permanent brood presence in colonies of A. mellifera. The main goal of this article was to evaluate the efficacy of a new formulation based on oxalic acid for when brood was present.

\section{MATERIAL AND METHODS}

Location of study. Summer field trials were carried out during March and April 2010 in the experimental apiary located near Bahía Blanca city (Buenos Aires, Argentina) and during January and February 2011 in the experimental apiary of The Charrúas Government (Downtown of Charrúas, Entre Ríos, Argentina). The average temperature recorded during this period in Bahia Blanca city was $22{ }^{\circ} \mathrm{C}$ (range $9-33^{\circ} \mathrm{C}$ ), and in Charrúas, the average was $31{ }^{\circ} \mathrm{C}$ (range $14-42{ }^{\circ} \mathrm{C}$ ). Autumn field trials were carried out during May and June 2013, in the experimental apiary of Arthropods Laboratory (National University of Mar del Plata), near Mar del Plata city. The average temperature recorded during this period was $14{ }^{\circ} \mathrm{C}$ (range $-2-20{ }^{\circ} \mathrm{C}$ ).

Field trials. Forty-eight beehives were used to assess product efficacy. Three experiments were conducted to test the efficacy of a new formulation with oxalic acid (Aluen CAP) made by Cooperativa de Trabajo Apícola Pampero Ltda. In the first two trials, the treatment efficacy was assessed during the summer season: one trial was performed in Bahía Blanca (15 colonies divided in three groups of five colonies each one: a control group "A" without treatment, a second control group "B" with celulose strips embebed with glycerin and a treatment group " $\mathrm{C}$ " with Aluen CAP) and the other in Charrúas (19 colonies divided in two groups: one of nine (control group) and the other of ten colonies (treatment group, Aluen CAP)). In a third trial, the honey and wax was tested for any OA residues (apiary located at Mar del Plata, 14 colonies divided in two groups of 7 colonies: control and treatment groups). All colonies used during trials were previously equalized for bee population, brood area, and honey and pollen stores. Hive bottoms specially adapted for the collection of dead mites were placed in each colony. In each trial, control groups without oxalic treatment were established. Apiaries were selected based on geographic locations at least $5 \mathrm{~km}$ away to avoid reinfestation phenomena.

At the beginning of the experiment, the new formulation were applied to the treatment group. Aluen Cap treatment consists of four strips U-shaped. The matrix of these strips is composed of cellulose $(45 \mathrm{~cm} \times 3 \mathrm{~cm} \times 1.5 \mathrm{~mm})$; each one contains $10 \mathrm{~g}$ of OA mixed with $20 \mathrm{~mL}$ of glycerin. Each strip was placed astride on frames 2, 4, 6, and 8 of the brood chamber (Figure 1). Falling mites were counted after $7,14,21,28,35$, and 42 days using the hive bottoms specially adapted for the collection of dead mites. After the last count, the strips were removed and at the same day, colonies received four flumethrin strips according to the instructions of the manufacturer (registered trade name: Flumevar ${ }^{\circledR}$, 


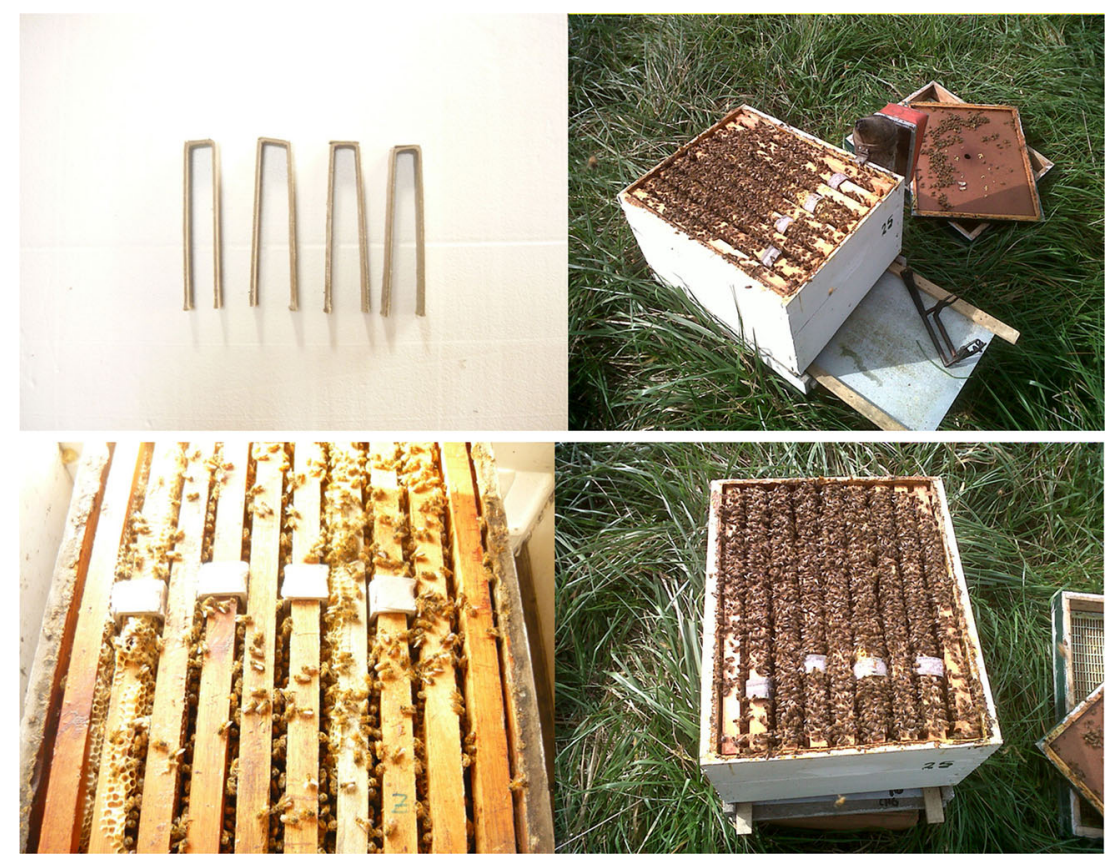

Figure 1. The application of the new formulation Aluen CAP, an organic product containing oxalic acid in strips of cellulose and glicerine to a hive.

supplied by APILAB SA, Argentina, http:// www.apilab.com/flumevarcostarica.pdf). No resistance phenomena to flumethrin had been reported previously in these apiaries or in the region where assays were performed. This treatment was left in the colonies for 45 days. Falling mites also were counted throughout this period.

The efficacy of oxalic acid treatment was calculated as a percentage: ((number of dead mites during oxalic acid treatment)/(number of dead mites collected during the treatment with OA and flumethrin) $\times 100$. The cumulative mite fall after oxalic acid and flumethrin treatment was assumed to be $100 \%$. Data on percent efficacy were analyzed by analysis of variance (ANOVA) after arcsine transformation in the case of percentages, to reduce the heterogeneity of the variance.

Colony population development. The progress of the hives treated with the oxalic acid was monitored prior to each treatment application and also 1 week after the acaricide application. As an example, at $T_{0}$, the colonies were inspected and the first treatment application was applied. Any change was compared with the untreated control hives. All other conditions (weather, nourishment, and supervision) were identical. The parameters to quantify the general state of the colonies during the evaluation were as follows: number of combs fully covered with bees and open and sealed brood areas. These procedures were satisfactory to assess colony development in previous research (Maggi et al. 2013; Negri et al. 2015). All colonies were checked by visual observations for dead brood bees and queens after treatment. Data were analyzed by ANOVA to evaluate if OA treatment produces changes in the variables measured.

\section{Oxalic acid extraction from bees, honey, and bees-} wax. During the autumn assay, samples of honey, bees, and wax were collected from colonies to detect possible residues generated by oxalic acid treatment. The bees were analyzed as a whole. Samples of each colony were taken prior the oxalic treatment application (control, timepoint $T_{0}$ ) and 42 days after it (timepoint $T_{2}$ ). Samples were collected according to the protocol of the European Working Group (2001) and were stored at $-80{ }^{\circ} \mathrm{C}$ until analysis. Ten grams of sample was then diluted with $80 \%$ ethanol. Beeswax sampled was heated in a water bath $62 \pm 2{ }^{\circ} \mathrm{C}$ for $15 \mathrm{~min}$ ); the samples had been previously acidified with $100 \mu \mathrm{L}$ of pure $\mathrm{HCl}$ $\left(\right.$ Merck $\left.^{\circledR}\right)$. Tubes were shaken vigorously for $1 \mathrm{~min}$. An aliquot of $50 \mu \mathrm{L}$ was placed in a $2-\mathrm{mL}$ vial and 
evaporated until dried, using a nitrogen stream. The extract was resuspended in $1 \mathrm{~mL}$ of ethanol: acid solution. Vials were placed in incubator at $50 \pm 2{ }^{\circ} \mathrm{C}$ for $5 \mathrm{~h}$.

GF-FID analysis. A gas chromatograph HP 6890 with a FID detector and an autosampler for 100 samples was used. For GF-FID analysis, an Austosampler Agilent 7683 was used. The injector conditions were: temperature, $100{ }^{\circ} \mathrm{C}$; pressure, 12.45 p.s.i.; split ratio, 10:1; and gas saver, $20 \mathrm{~mL} / \mathrm{min}$. An Agilent Column $(30 \mathrm{~m} \times 0.25 \mathrm{~m} \times 0.25 \mu \mathrm{m}$ HP-5MS Ultra Inerte $(\mathrm{p} / \mathrm{n}$ 19091S-433UI)) was employed using Helium 5.0 (Praxair) in constant pressure mode (flow, $1 \mathrm{~mL} / \mathrm{min}$; oven temperature, $50^{\circ} \mathrm{C}$; injection volume, $1 \mu \mathrm{L}$; detector: FID: temperature, $250{ }^{\circ} \mathrm{C}$ ) as gas carrier. The average recovery of the oxalic acid ranged from 87 to $110 \%$, and detection limits were honey: detection limit, $0.5 \mathrm{mg} / \mathrm{kg}$-quantification limit, $1 \mathrm{mg} / \mathrm{kg}$; wax: detection limit, $1.5 \mathrm{mg} / \mathrm{kg}$-quantification limit, $12 \mathrm{mg} / \mathrm{kg}$; bees: detection limit, $0.8 \mathrm{mg} / \mathrm{kg}$-quantification limit, $2 \mathrm{mg} / \mathrm{kg}$. Data were analyzed by ANOVA to evaluate if OA treatment produces changes in the variables measured.

\section{RESULTS}

Efficacy. The efficacy of the treatment in Varroa control was determined by comparing the number of falling mites recorded during the oxalic acid treatment period with the total number of falling mites recorded during the whole trial (including the flumethrin treatment). Results are presented in Table I. The average final efficacy in colonies treated with the new oxalic acid formulation was $94 \%$ (in the experimental apiary located near to Charrúas dowtown, summer trial), $92.7 \%$ (in experimental apiary placed near to Bahia Blanca city, summer trial) and $92.8 \%$ (in experimental apiary placed near to Mar del Plata city, autumn trial). Final efficacy of the OA treatment had significant differences to the control $(P<0.05)$. All trials had a low variability in the final efficacy (range between $85.9 \pm 98.8 \%$ ). The highest mortality for the three assays was recorded during the first 22 days, with an average partial efficacy of $74.4 \%$.

Effects on colony population Colony population parameters before and after treatment are shown in Table II. For summer trials, treated colonies (oxalic acid treatment) finished with an average of 4.5 brood combs and 8.2 frames of bees. In the autumn trial, colonies finished with 3.2 combs covered with brood (open+sealed brood) and 8 frames covered with adult bees. Adverse effects on the colonies (dead bee brood or queens) were not detected during and after treatment. Adverse effects on the bee populations were not detected in the treated colonies in all three trials $(P>0.05)$.

Oxalic acid detection from bees, honey and beeswax. Table III summarizes the measurements of oxalic acid in all samples taken before and after treatment. The natural oxalic acid content varied between 2.5 and $33.8 \mathrm{mg} / \mathrm{kg}$. There was no increase in oxalic acid content of honey, wax, and bees after treatments, in all three trials $(P>0.05)$. All samples of bees and beeswax were negative before and after the OA treatment.

\section{DISCUSSION}

The new formulation with oxalic acid as the active ingredient, presents some advantages over the current methods of organic acid treatments. Polymer-cellulose matrices not only have all the benefits of the oxalic acid liquid treatments but also delay the release of OA so that it can remain longer in the colony (Eguaras et al. 2003). This reduces the number of visits to apiaries to reapply OA treatments. In this study, we report a new formulation based on oxalic acid with high acaricide activity against $V$. destructor. However, taking into account that mite fall was registered with hive bottom specially adapted, the estimated efficacy results not exclusively from the application of the test medication but also from a combinatory effect (natural mite mortality). Nonetheless, strong differences were detected with the control group, demonstrating an excellent acaricide activity of the new treatment.

Other research has demonstrated that good efficacy has been obtained using at least three applications of liquid oxalic acid per colony. In other cases, three or more applications were not enough for effective Varroa control (Rademacher and 


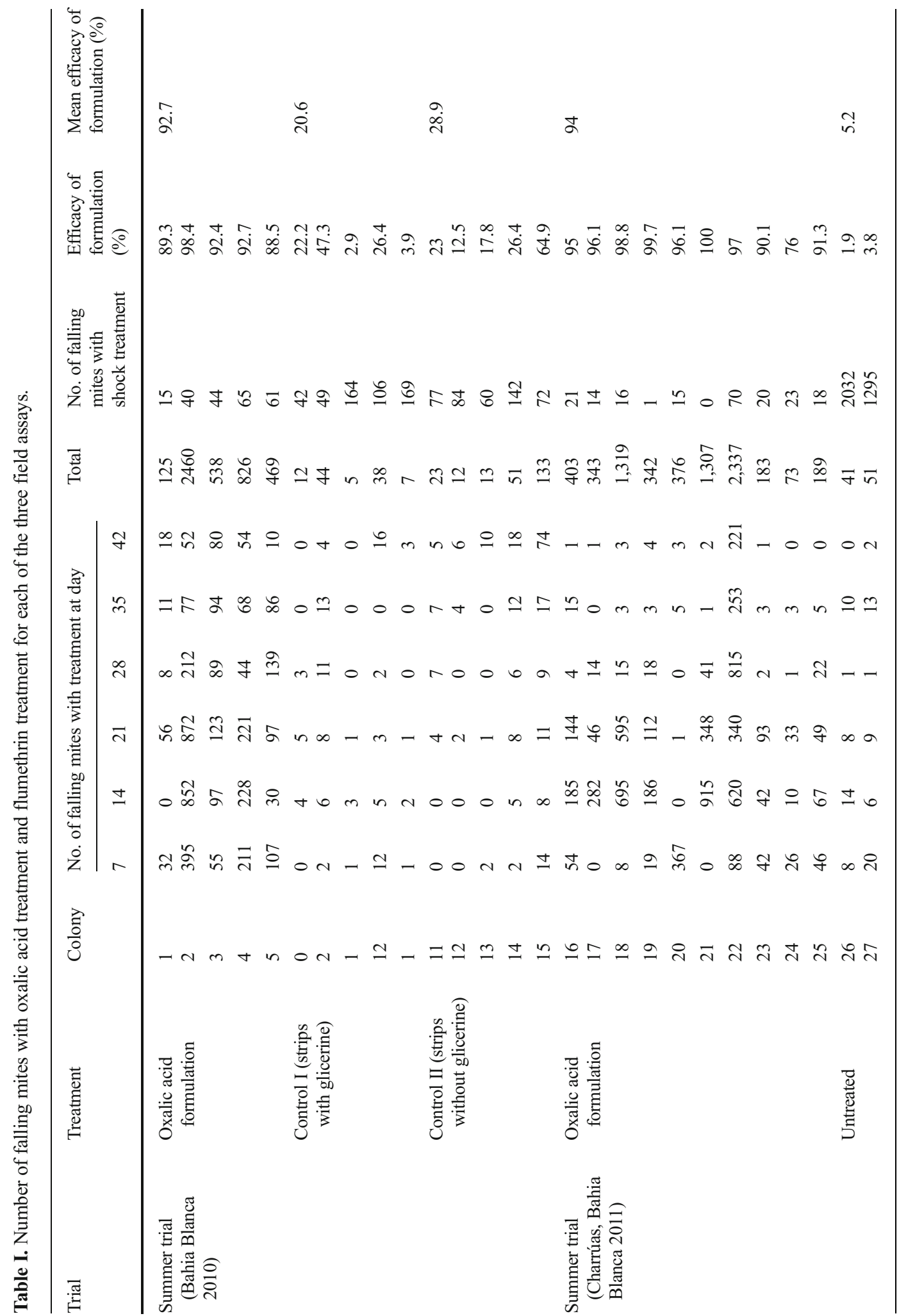




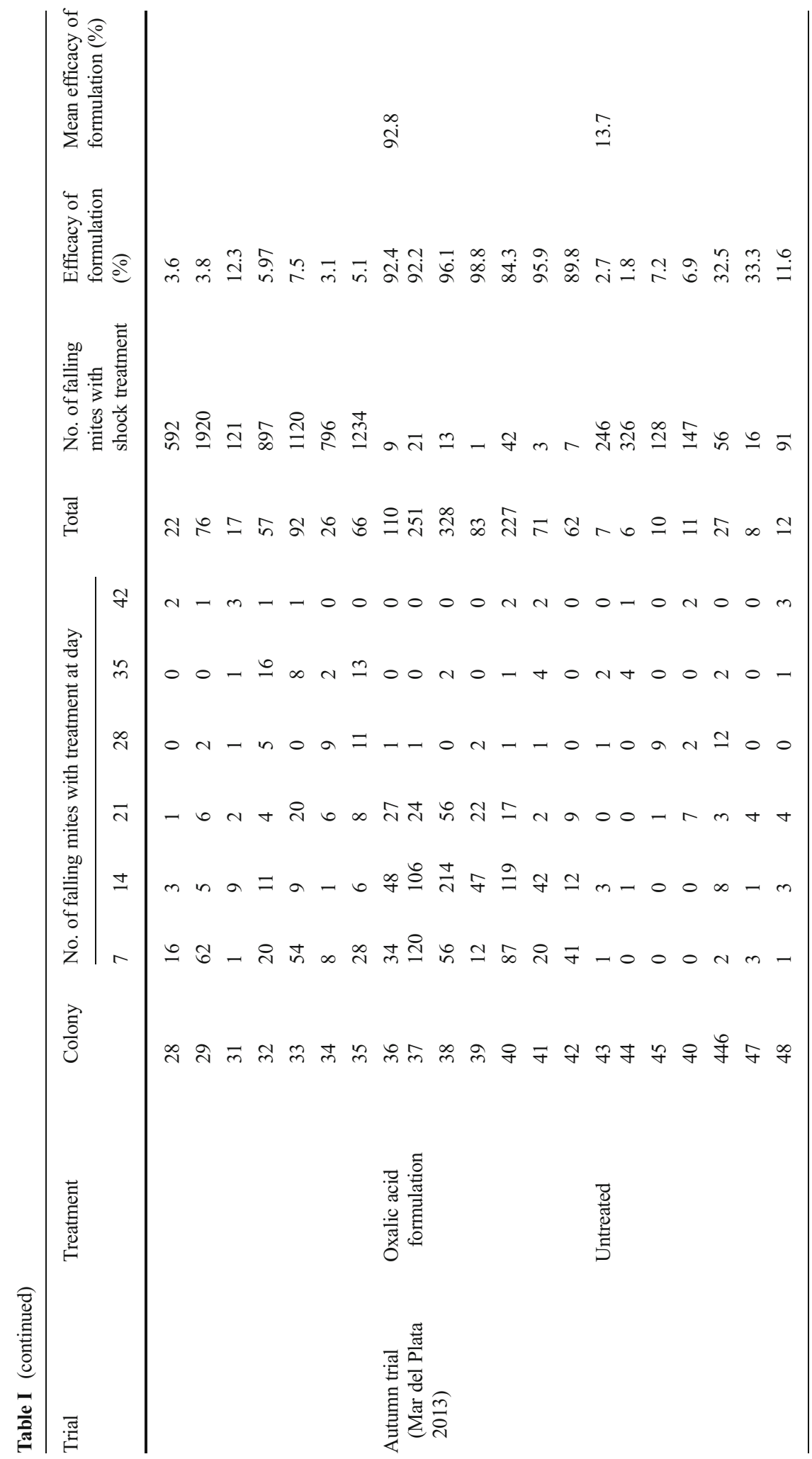


Harz 2006). Also, during the summer season, the efficacy obtained by liquid treatments is reduced as oxalic acid does not kill the mites in sealed brood cells. In addition, Hatjina and Haristos (2005) have shown a detrimental effect on brood development plus low effectiveness using the trickling method of OA when open brood is present. They suggest that this method is not as safe as has been reported in the past.

Marinelli et al. (2006) evaluated the efficacy of cellulose strips with oxalic acid in comparison with other oxalic acid treatments (trickling and vaporization methods). In spring trials, the effectiveness of the cellulose strips was not statistically different from the natural fall of Varroa . Similarly, the autumn trials had the same results. However, when spraying, trickling, and vaporizing oxalic acid, good control of Varroa was seen in central Italy. They conclude that the unsatisfactory efficacy of cellulose strips versus the good control results of trickling and vaporization could be explained by the high acidity of the oxalic acid water solutions. A pH around 1 may be responsible for the best oxalic acid activity against the mites. Here, we show that one application of the Aluen Cap formulations is enough to have good mite control even with the presence of bee brood. In this study, the oxalic acid formulation had a high efficacy and it was possible to keep low Varroa prevalence indices in the colonies. The matrix of the OA strip may help to keep an adequate acid concentration inside the colonies for a long time (42 days). In addition, the combination of glycerin with AO could help to maintain the drug for a longer time inside the beehive and consequently with mites (including those that are emerging from brood cells). As it was reported by Segur and Oberstar (1951), glycerin possesses a high viscosity. This chemical property would help to disseminate the acid among bees during a longer time in comparison with other strip formulations without glycerin, increasing its efficacy (these hypotheses should be examined in later studies). During the season when this work was done, the temperature range was $-2-42{ }^{\circ} \mathrm{C}$, and in the three trials, there were no problems with the higher temperatures in the colonies.

This new product offers a good alternative for Varroa control as it does not have the two most 
Table III. Oxalic acid residues in wax, bees and honey after treatment.

\begin{tabular}{|c|c|c|c|}
\hline Treatment & Matrix & Before treatment & After treatment \\
\hline \multirow[t]{3}{*}{ Control } & Wax & $0(7)$ & $0(7)$ \\
\hline & Bees & $0(7)$ & $0(7)$ \\
\hline & Honey & $14.2^{\mathrm{b}} \pm 11.6(7)$ & $25.6^{\mathrm{c}} \pm 12.5(7)$ \\
\hline \multirow[t]{3}{*}{ OA } & Wax & $0(7)$ & $0(7)$ \\
\hline & Bees & $0(7)$ & $0(7)$ \\
\hline & Honey & $7.5^{\mathrm{a}} \pm 5.2(7)$ & $17.3^{\mathrm{b}} \pm 15(7)$ \\
\hline
\end{tabular}

Mean \pm standard deviations (SD) and number of samples $(n)$. Honey: detection limit, $0.5 \mathrm{mg} / \mathrm{kg}$-quantification limit, $1 \mathrm{mg} / \mathrm{kg}$; wax detection limit, $1.5 \mathrm{mg} / \mathrm{kg}$-quantification limit, $12 \mathrm{mg} / \mathrm{kg}$; bees: detection limit, $0.8 \mathrm{mg} / \mathrm{kg}$-quantification limit, $2 \mathrm{mg} / \mathrm{kg}$. Uppercase letters $(\mathrm{a}-\mathrm{c})$ indicate statistical differences among treatments $(t$ test, $P<0.05)$

frequent disadvantages of organic products used for mite control. First, it is easy to use, safe for beekeepers, and presents low variability between colonies in its efficacy. Second, it does not present a risk to colony development and so it can be used to safely reduce the damage done by Varroa mites even during the summer season.

In Argentina (as in many other parts of the world), the use of synthetic acaricides is being restricted due to the emergence of resistant mite populations (Maggi et al. 2009, 2010a, 2011; Sammataro et al. 2005), as well as honey and wax contamination (Bogdanov et al. 2003; Wallner 1999; Medici et al. 2015). Oxalic acid is a natural constituent of honey; values between 8 and $17,000 \mathrm{mg} / \mathrm{kg}$ have been found in different honeys (Mutinelli et al. 1997; Bernardini and Gardi 2001; Bogdanov et al. 2002).

Most vegetables contain much higher amounts of oxalic acid than honey so the total daily intake is negligible. Thus, from a nutritional point of view, oxalic acid should, like formic acid, also have a generally recognized as safe (GRAS) status. Moreover, no significant residues are expected after oxalic acid treatments as demonstrated in our research. Indeed, there is no risk of honey residues after all types of oxalic acid treatments (Radetzki 1994; Mutinelli et al. 1997; Del Nozal et al. 2000; Bernardini and Gardi 2001; Radetzki and Barmann 2001; Bogdanov et al. 2002).

Spraying and trickling of oxalic acid are accepted for use against $V$. destructor in most European countries and are widely used by beekeepers throughout Europe (Charriere and Imdorf 2002).
This new formulation is not dangerous for the user or for the bee colony. Thus, Aluen CAP could be a valid alternative for Varroa mite control.

\section{ACKNOWLEDGMENTS}

The authors would like to thank the Universidad Nacional de Mar del Plata (UNMDP) and Consejo Nacional de Investigaciones Científicas y Técnicas (CONICET). This research was supported by a grant of ANPCyT, PICT 2011 to M.M.

Une nouvelle formulation de l'acide oxalique appliquée dans les colonies d' Apis mellifera pour lutter contre Varroa destructor, en présence du couvain

Acari / lutte antiparasitaire / couvain d'abeille / Argentine

Eine neue Oxalsäure-Formulierung zur Bekämpfung von Varroa destructor in Völkern von Apis mellifera mit Brut

Varroa destructor / Bekämpfung / Oxalsäure / Bienenbrut / Argentinien

\section{REFERENCES}

Bacandritsos, N., Papanastasiou, I., Saitanis, C., Nanetti, A., Roinioti, E. (2007) Efficacy of repeated trickle applications of oxalic acid in syrup for varroosis control in Apis mellifera: Influence of meteorological conditions and presence of brood. Vet. Parasitol. 148, 174-178 
Barbero, R., Panella, F., Bonizzoni, L. (1997) Ácido oxálico y el tratamiento de limpieza radical de otoñoinvierno. Vida Apícola 85, 8-13

Bernardini, M., Gardi, T. (2001) Influence of acaricide treatments for Varroa control on the quality of honey and beeswax. Apitalia 28(7-8), 21-24

Bogdanov, S., Charriere, J., Imdorf, A., Kilcheman, V., Fluri, P. (2002) Determination of residues in honey after treatments under field conditions with formic and oxalic acid. Apidologie 33(4), 399409

Bogdanov, S., Kilchenmann, V., Butikofer, U. (2003) Determination of acaricide residues in beeswax: Collaborative study. Apiacta 38(3), 235-245

Charrière, J.D. (1997) Potentiel et limites de l'emploi des acides organiques. Sanitaire 161, 219-227

Charrière, J.D., Imdorf, A. (2002) Oxalic acid treatment by trickling against Varroa destructor: recommendations for use in central Europe and under temperate climate conditions. Bee World $83(2), 51-60$

Del Nozal, M., Bernal, J., Diego, J., Gomez, L., Ruiz, J., Higes, M. (2000) Determination of oxalate, sulfate and nitrate in honey and honeydew by ion-chromatography. J. Chromat. A 881, 629638

Eguaras, M., Ruffinengo, S. (2006) Estrategias para el control de Varroa. Ed. Martin, Mar del Plata.

Eguaras, M., del Hoyo, M., Palacio, A., Ruffinengo, S., Bedascarrasbure, E. (2001) A new product with formic acid for Varroa jacobsoni control. I Efficacy. J. Vet. Med., (Series b), 48, 11-14

Eguaras, M., Palacio, A., Faverin, C., Basualdo, M., Del Hoyo, M., Velis, G., Bedascarrasbure, E. (2003) Efficacy of formic acid in gel for Varroa control in Apis mellifera: importance of the dispenser position inside the hive. Vet. Parasitol. 111, 241-245

Gregorc, A., Planinc, I. (2001) Acaricidal effect of oxalic acid in honeybee (Apis mellifera) colonies. Apidologie 32, 333-340

Gregorc, A., Planinc, I. (2002) The control of Varroa destructor using oxalic acid. Vet. J 163, 306-310

Hatjina, F., Haristos, L. (2005) Indirect effects of oxalic acid administered by trickling method on honey bee brood. J. Apic. Res. 44 (4), 172-174

Higes, M., Meana, A., Suárez, M., Llorente, J. (1999) Negative long-term effects on bee colonies treated with oxalic acid against Varroa jacobsoni Oud. Apidologie 30, 289-292

Imdorf, A., Charrière, J.D., Kilchenmann, V., Bogdanov, S., Fluri, P. (2003) Alternative strategy in central Europe for the control of Varroa destructor in honey bee colonies. Apiacta 38, 258-278

Maggi, M., Ruffinengo, S., Damiani, N., Sardella, N., Eguaras, M. (2009) A first detection of Varroa destructor resistance to coumaphos in Argentina. Exp. App. Acarol. 47 (4), 317-320
Maggi, M., Ruffinengo, S., Negri, P., Eguaras, M. (2010a) Resistance phenomena to amitraz from populations of the ectoparasitic mite Varroa destructor of Argentina. Parasitol. Res. 107 (5), 1189-1192

Maggi, M., Ruffinengo, S., Gende, L., Sarlo, G., Bailac, P., Ponzi, M., Eguaras, M. (2010b) Laboratory evaluations of Syzygium aromaticum (L.) Merr. et Perry essential oil against Varroa destructor. J. Ess. Oil Res 22, 119-122

Maggi, M., Ruffinengo, S., Mendoza, Y., Ojeda, P., Ramallo, G., Floris, I., Eguaras, M. (2011) Susceptibility of Varroa destructor (Acari: Varroidae) to synthetic acaricides in Uruguay: Varroa mites' potential to develop acaricide resistance. Parasitol. Res. 108, 815821

Maggi, M., Negri, P., Plischuk, S., Szawarski, N., De Piano, F., De Feudis, L., Eguaras, M., Audisio, C. (2013) Effects of the organic acids produced by a lactic acid bacterium in Apis mellifera colony development, Nosema ceranae control and fumagillin efficiency. Vet. Microbiol. doi:10.1016/j.vetmic.2013.07.030

Marinelli, E., Formato, G., Vari, G., De Pace, F.M. (2006) Varroa control using cellulose strips soaked in oxalic acid water solution. Apiacta 41, 54-59

Medici, S., Maggi, M., Sarlo, E., Ruffinengo, S., Marioli, J., Eguaras, M. (2015) Presence of syntethic acaricides in beeswax and its relationship with the development of resistance in Varroa destructor. J. Apic. Res, in press

Mutinelli, F., Baggio, A., Capolongo, F., Piro, R., Prandin, L., Biaison, L. (1997) A scientific note on oxalic acid by topical application for the control of varroosis. Apidologie 28(6), 461-462

Nanetti, A., Büchler, R., Charriere, J.-D., Fries, I., Helland, S., Imdorf, A., Korpela, S., Kristiansen, P. (2003) Oxalic acid treatments for Varroa control (review). Apiacta 38, 81-87

Negri, P., Maggi, M., Ramirez, L., De Feudis, L., Szwarski, N., Eguaras, M., Lamattina, L. (2015) Abscisic acid enhances the immune response in Apis mellifera and contributes to the colony fitness. Apidologie 46(4), 542-557

Rademacher, E., Harz, M. (2006) Oxalic acid for the control of varroosis in honey bee colonies - a review. Apidologie 37, 98-120

Radetzki, T. (1994) Oxalsäure, eine weitere organische Säure zur Varroabehandlung. Allgemeine Deutsche Imkerzeitung 28(12), 11-15

Radetzki, T., Bärmann, M. (2001) Verdampfungsverfahren mit Oxalsäure. Feldversuch mit 1509 Völkern im Jahr 2000. Allgemeine Deutsche Imkerzeitung 35(9), 20 23

Ruffinengo, S., Maggi, M., Fuselli, S., De Piano, F., Negri, P., Brasesco, C., Satta, A., Floris, I., Eguaras, E. (2014) Bioactivity of microencapsulated essentials oils and perspectives of their use in the control of Varroa destructor. Bull. Insectol. 67(1), 81-86 
Sammataro, D., Untalan, P., Guerro, F., Finley, J. (2005) The resistance of Varroa mites (Acari: Varroidae) to acaricides and the presence of esterase. Int. J. Acarol. 31 (1), 67-74
Segur, J., Obrstar, H. (1951) Viscosity of glycerol and its aqueous solutions. Ind. Eng. Chem. 43 (9), 2117-2120

Wallner, K. (1999) Varroacids and their residues in bee products. Apidologie 30, 235-248 